Biol. Stud. 2016: 10(1); 133-142 • DOI: https://doi.org/10.30970/sbi.1001.465

www.http://publications.Inu.edu.ua/journals/index.php/biology

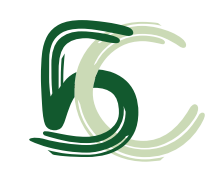

UDC 582. 282 (477. 83:292. 452)

\title{
ECOLOGICAL FEATURES OF NEW SPECIES OF XYLOTROPHIC PYRENOMYCETES (ASCOMYCOTA) FOR SKOLIVSKI BESKYDY
}

Ya. Bublyk

Ivan Franko National University of Lviv, 4, Hrushevskyi St., Lviv 79005, Ukraine

State Museum of Natural History, NAS of Ukraine, 18, Teatralna St., Lviv 79008, Ukraine

e-mail: bublykyaroslav1302fungi@gmail.com

The fieldwork was carried out from the end of September to early December 2015, during the main fruiting period. At this time, on the territory of Skolivski Beskydy, we found 26 new species of xylotrophic pyrenomycetes. These species represent 20 genera, 14 families, 8 orders, 3 subclasses (Hypocreomycetidae, Sordariomycetidae and Xylariomycetidae), the class Sordariomycetes, the subphylum Pezizomycotina in the Ascomycota phylum. Sordariomycetidae is represented by the largest number of species (17). Six species of xylotrophic pyrenomycetes belong to Xylariomycetidae subclass. The smallest number of species (3) of xylotrophic pyrenomycetes in the forest ecosystems of Skolivski Beskydy were established in Hypocreomycetidae subclass. Only three species belong to Incertae sedis Sordariomycetes. All new xylotrophic pyrenomycetes were found on thirteen species represented by eleven genera of tree plants. The highest number of species (13) of perithecial fungi were found on Fagus sylvatica L. Most of the established xylotrophic fungi (19 species) were found on branches and twigs, while only 7 - on stems. The largest number of fungi (17 species) were found on the earliest decay stages of dead wood. Most of the identified xylotrophic pyrenomycetes are corticolous destructors of dead wood, and lignicolous saprotrophs constitute much smaller part. For each of the identified species, its wood substrate, accommodation in the ecological niche and specialization of the species to decay stages of dead wood by the Renvall scale are presented.

Keywords: xylotrophic pyrenomycetes, ecological niches, forest ecosystems, dead wood, Eastern Carpathians.

\section{INTRODUCTION}

Fungi play an important role in forest ecosystems. They are principal decomposers of dead organic matter, such as dead wood and litter. For saprotrophic fungi, dead wood is one of the most important substrates in forests [15]. An important and still insufficiently investigated group of saprotrophic fungi are xylotrophic or wood-inhabiting fungi. These are the fungi that decompose dead wood [28]. Xylotrophic pyrenomycetes are one of the most important wood decomposing fungi [3].

ISSN 1996-4536 (print) • ISSN 2311-0783 (on-line) • Біологічні Студії / Studia Biologica • 2016 • Том 10/№1 • C. 133-142 
One of insufficiently investigated groups of xylotrophic fungi are wood-inhabiting pyrenomycetes. Pyrenomycetes are fungi that occur primarily as perithecial ascomata (flask-shaped fruiting bodies) on a wide range of substrates [12; 29]. Pyrenomycetes occur in all ecosystems and geographical areas throughout the world primarily as saprobes where they play an integral role in the nutrient cycle and decomposition of the organic matter [25].

The fungal diversity of Ukraine is still insufficiently and unevenly investigated. The Skolivski Beskydy demonstrate an exclusive situation. The first study of fungal diversity on the territory of the Skolivski Beskydy was conducted by J. Krupa [13; 14]. Untill recently there were no research data on the fungal diversity of this important area [6]. This work is a continuation of a series of publications devoted to the biological diversity and ecological features of sac fungi, including xylotrophic pyrenomycetes in the forest ecosystems of the Skolivski Beskydy. To date, only information on 115 species of xylotrophic pyrenomycetes (Ascomycota) has been reported [5].

With this work we make a further contribution to the fungal diversity investigation in Skolivski Beskydy region. The study continues the research of fungal diversity in the forest ecosystems of Skolivski Beskydy.

\section{DESCRIPTION OF THE STUDY AREA}

Skolivski Beskydy are located in the Subcarpathian upland region of the Ukrainian Carpathian Mountains within the boundaries of Skole, Drohobych, and Turka districts of the Lviv region. They are located in the basins of the Stryi and the Opir rivers [16].

Their absolute heights range from 600 to 1,200 meters. The climate of Skolivski Beskydy is mild, moderately warm and humid. Winter is characterised by frequent thaws and the temperature ranging from $0{ }^{\circ} \mathrm{C}$ to $+5{ }^{\circ} \mathrm{C}$. The average temperature in January is about $-5^{\circ} \mathrm{C}$, in July $-+17^{\circ} \mathrm{C}$. The annual precipitation is $800-1,100 \mathrm{~mm}$. The average thickness of snow cover is $39 \mathrm{~cm}$.

On the territory of Skolivski Beskydy one can still find the remains of pure beech forests and spruce fir forest stands, the totality of which occupies the highest position in the area's relief. On some ridges there are rare beech, sycamore and alder forests. The most common on the territory are fir, spruce, beech-fir, and spruce-fir-beech forests with occasional sycamore and grey alder forests [22].

\section{MATERIALS AND METHODS}

The study was conducted in forest ecosystems during the autumn period of 2015 by following the field method. Specimens of xylotrophic pyrenomycetes were collected by the author. They are deposited in the herbarium of the State Museum of Natural History of the NAS of Ukraine (LWS). Attention was paid to xylotrophic pyrenomycetes on wood and bark of decaying tree species. The following indexes were registered: wood substrate, stages of degradation of dead wood and the ecological niche [2].

The found fruit bodies were identified on the site of sampling or in laboratory conditions. Microscopic features were examined in $5 \%$ solution of $\mathrm{KOH}$ [12]. The micromorphological investigation of specimens was performed by using MicroMed XS-2610 (LOMO, Russian).

For identification of the specimens a number of monographs and papers on systematics and biodiversity of fungi were used $[4 ; 7 ; 8 ; 10 ; 17 ; 18 ; 20 ; 21 ; 23 ; 26 ; 27]$.

ISSN 1996-4536 (print) • ISSN 2311-0783 (on-line) • Біологічні Студії / Studia Biologica • 2016 • Том 10/№1 • С. 133-142 
The nomenclature of the species follows the Index Fungorum database [11]. Their systematic characterization is in accordance with Kirk et al. [12]. The names of the substrata-forming plant species are as in Mosyakin and Fedoronchuk [19], so the authors of these plant names are skipped in the text below. The possibility of the species occurrence on Ukraine's territory was checked by using the "Fungi of Ukraine" database [1] and other recently published papers and monographs devoted to the biodiversity of Ukrainian fungi [9].

Decay stages were defined following a modified Renvall classification [24].

\section{RESULTS AND DISCUSSION}

The study has identified 26 new species of xylotrophic pyrenomycetes for Skolivski Beskydy. The identified fungi belong to the Ascomycota phylum, the Pezizomycotina subphyllum, the Sordariomycetes class. Sordariomycetes is represented by 3 subclasses (Hypocreomycetidae, Sordariomycetidae and Xylariomycetidae).

Sordariomycetidae is represented by the largest number of species (17). These xylotrophic pyrenomycetes belong to 4 orders: Boliniales, Chaetosphaeriales, Diaporthales and Sordariales. Diaporthales is represented by the largest number of species (8) and Sordariales - by the lowest (4 species). The orders of Boliniales and Chaetosphaeriales are represented in one species (Camarops tubulina (Alb. \& Schwein.) Shear and Chaetosphaeria sp. in the anamorphic stage Gonytrichum macrocladum (Sacc.) S. Hughes, respectevly).

Six species of xylotrophic pyrenomycetes belong to the Xylariomycetidae subclass. These species represent 3 families: Xylariaceae (3 species), Diatrypaceae (2 species) and Amphisphaeriaceae (lodosphaeria sp. in the anamorphic stage Ceratosporium gracile Matsush). The smallest number of species (3) of xylotrophic pyrenomycetes in the forest ecosystems of Skolivski Beskydy were established in the Hypocreomycetidae subclass. This class is represented by the Coronophorales and Hypocreales orders. Coronophorales comprises 2 families (Chaetosphaerellaceae is represented by Chaetosphaerella fusca (Fuckel) E. Müll. \& C. Booth in the anamorphic stage Oedemium didymum (J.C. Schmidt) S. Hughes; Nitschkiaceae - by Nitschkia confertula (Schwein.) Nannf.), Hypocreales is represented only by one - Nectriaceae (Nectria nigrescens Cooke + the anamorphic stage).

Only three species belong to Incertae sedis Sordariomycetes (Cryptadelphia polyseptata Réblová \& Seifert in the anamorphic stage Brachysporium polyseptatum (Preuss.) S. Hughes, C. sp. in the anamorphic stage B. obovatum (Berk.) Sacc. and Fluviostroma wrightii Samuels \& E. Müll.) The identified species of xylotrophic pyrenomycetes are listed in the systematic order and among the taxa of the same range - in the alphabetical order.

Ascomycota Caval.-Sm.

Pezizomycotina O.E. Erikss. \& Winka

Sordariomycetes O.E. Erikss. \& Winka

Hypocreomycetidae O.E. Erikss. \& Winka

Coronophorales Nannf.

Nitschkiaceae Nannf.

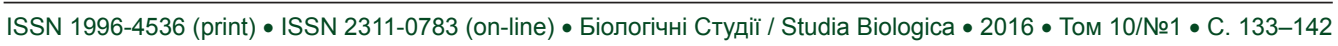


1. Nitschkia confertula (Schwein.) Nannf.

Chaetosphaerellaceae Huhndorf, A.N. Mill. \& F.A. Fernández

2. Chaetosphaerella fusca (Fuckel) E. Müll. \& C. Booth in the anamorphic stage Oedemium didymum (J.C. Schmidt) S. Hughes

Hypocreales Lindau

Nectriaceae Tul. \& C. Tul.

3. Nectria nigrescens Cooke + the anamorphic stage

Sordariomycetidae O.E. Erikss. \& Winka

Boliniales P.F. Cannon

Boliniaceae Rick

4. Camarops tubulina (Alb. \& Schwein.) Shear

Chaetosphaeriales Huhndorf, A.N. Mill. \& F.A. Fernández

Chaetosphaeriaceae Réblová, M.E. Barr \& Samuels

5. Chaetosphaeria sp. in the anamorphic stage Gonytrichum macrocladum (Sacc.) $\mathrm{S}$. Hughes

Diaporthales Nannf.

Diaporthaceae Höhn. ex Wehm.

6. Diaporthe eres Nitschke + the anamorphic stage Phomopsis oblonga (Desm.) Traverso

7. Diaporthe pustulata Sacc.

8. Diaporthe sp. in the anamorphic stage Phomopsis juniperivora G.G. Hahn

9. Diaporthe syngenesia (Fr.) Fuckel

Melanconidaceae G. Winter

10. Melogramma spiniferum (Wallr.) De Not.

11. Melanconis alni Tul. \& C. Tul.

12. Prosthecium pyriforme Jaklitsch \& Voglmayr in the anamorphic stage Stegonsporium pyriforme (Hoffm.) Corda

Valsaceae Tul. \& C. Tul.

13. Valsa abietis Fr.

Sordariales Chadef. ex D. Hawksw. \& O.E. Erikss.

Helminthosphaeriaceae Samuels, Cand. \& Magni

14. Endophragmiella ellisii S. Hughes

Lasiosphaeriaceae Nannf.

15. Lasiosphaeria phyllophila Mouton

16. Lasiosphaeria punctata Munk (=Hilberina punctata (Munk) A.N. Mill. \& Huhndorf) + the anamorphic stage Endophragmiella biseptata (Peck) S. Hughes

Incertae sedis Sordariales

17. Brachysporiella setosa (Berk. \& M.A. Curtis) M.B. Ellis

Xylariomycetidae O.E. Erikss. \& Winka

Xylariales Nannf.

Amphisphaeriaceae G. Winter

18. lodosphaeria sp. in the anamorphic stage Ceratosporium gracile Matsush

Diatrypaceae Nitschke

19. Eutypa sparsa Romell

20. Libertella aucupariae Oudem.

ISSN 1996-4536 (print) •ISSN 2311-0783 (on-line) • Біологічні Студії / Studia Biologica • 2016 • Том 10/№1 • С. 133-142 
Xylariaceae Tul. \& C. Tul.

21. Daldinia childiae J.D. Rogers \& Y.M. Ju

22. Daldinia fissa Lloyd

23. Nemania effusa (Nitschke) Pouzar

Incertae sedis Sordariomycetes

Trichosphaeriales M.E. Barr

Trichosphaeriaceae G. Winter

24. Cryptadelphia polyseptata Réblová \& Seifert in the anamorphic stage Brachysporium polyseptatum (Preuss.) S. Hughes

25. Cryptadelphia sp. in the anamorphic stage Brachysporium obovatum (Berk.) Sacc.

26. Fluviostroma wrightii Samuels \& E. Müll.

Three substrate indices were considered: ecological niches, wood decay stages (degree of decomposition) and host tree species.

All new species of xylotrophic pyrenomycetes were found on eleven host genera represented by thirteen species: Abies alba Mill., Acer platanoides L., Acer pseudoplatanus L., Alnus glutinosa (L.) Gaerth, Alnus incana (L.) Moench., Corylus avellana L., Fagus sylvatica L., Frangula alnus Mill., Fraxinus excelsior L., Juniperus communis L., Piceae abies (L.) Karsten, Populus nigra L., Sorbus aucuparia L.

The highest number of species of xylotrophic pyrenomycetes were found on Fagus sylvatica (13), and the lowest (3 species on each) on dead wood of Alnus incana, Acer pseudoplatanus, Populus nigra. Two species were idetified on wood of Abies alba and Juniperus communis. Each of the remaining seven substrates of wood is represented by one species.

According to the ecological niche, the following classification of woody debris was used: 1) branches and twigs of the diameter 3-10 $\mathrm{mm}$; 2) branches of the diameter $10-15 \mathrm{~mm}$; 3) branches of the diameter from 15 to $25 \mathrm{~mm}$; 4) branches of the diameter $\geq 25 \mathrm{~mm}$; 5) the upper part of the stem; 6) the middle part of the stem; 7) the lower part of the stem (including stumps).

Decay stages were defined following modified Renvall classification (1995): (I) hard wood, trunks or branches as solid pieces, where a knife penetrates only a few $\mathrm{mm}$ into the wood; (II) fairly hard wood, bark usually present but not always firmly attached, where a knife penetrates 1-2 cm into the wood; (III) fairly soft wood, small areas of sapwood already decomposed and without bark where a knife penetrates easily; (IV) soft wood, extensively decayed and usually large sections of the wood completely decomposed, where a knife penetrates through the wood easily; (V) very soft wood, almost completely decomposed which disintegrates easily between fingers. The decay stages were obtained for each fungal species, found in the area of fruitbodies growth.

More information on the ecological features of the new species of xylotrophic pyrenomycetes in the forest ecosystems of Skolivski Beskydy are shown in the Table. The table shows a number of the ecological niches for each xylotrophic pyrenomycetes. As shown in the table, the largest part of the species (8) occured on branches of the diameter $\geq 25 \mathrm{~mm}$, while on branches and twigs of the diameter $3-10 \mathrm{~mm}$ were found 6 , on branches of the diameter from 15 to $25 \mathrm{~mm}$ and on the middle part of the stem - 4 species. A smaller number of species (3) was found on branches of the 10-15 mm diameter and on the upper part of the stem, while on the lower part of the stem - 1 species.

ISSN 1996-4536 (print) • ISSN 2311-0783 (on-line) • Біологічні Студії / Studia Biologica • 2016 • Том 10/№1 • С. 133-142 


\section{Ecological features of the xylotrophic pyrenomycetes in forest ecosystems of Skolivski Beskydy \\ Екологічні особливості ксилотрофних піреноміцетів у лісових екосистемах Сколівських Бескидів}

\begin{tabular}{|c|c|c|c|c|}
\hline No & Species & Host & $\begin{array}{l}\text { Ecological } \\
\text { niche }\end{array}$ & $\begin{array}{l}\text { Decay } \\
\text { stage }\end{array}$ \\
\hline 1 & Nitschkia confertula & Fraxinus excelsior & 6 & III \\
\hline 2 & $\begin{array}{l}\text { Chaetosphaerella fusca in the } \\
\text { anamorphic stage Oedemium } \\
\text { didymum }\end{array}$ & Alnus incana & 4 & III \\
\hline 3 & Nectria nigrescens & Acer platanoides & $1,2,3$ & I \\
\hline 4 & Camarops tubulina & Abies alba, Picea abies & 6 & II \\
\hline 5 & $\begin{array}{l}\text { Chaetosphaeria sp. in the anamorphic } \\
\text { stage Gonytrichum macrocladum }\end{array}$ & Fagus sylvatica & 4 & III \\
\hline 6 & $\begin{array}{l}\text { Diaporthe eres }+ \text { the anamorphic } \\
\text { stage Phomopsis oblonga }\end{array}$ & Fagus sylvatica & 2 & I \\
\hline 7 & Diaporthe pustulata & Fagus sylvatica & 2 & II \\
\hline 8 & $\begin{array}{l}\text { Diaporthe sp. in the anamorphic stage } \\
\text { Phomopsis juniperivora }\end{array}$ & Juniperus communis & 1 & I \\
\hline 9 & Diaporthe syngenesia & Frangula alnus & 1 & I \\
\hline 10 & Melogramma spiniferum & Fagus sylvatica & 7 & I \\
\hline 11 & Melanconis alni & Alnus glutinosa & 4 & II \\
\hline 12 & $\begin{array}{l}\text { Prosthecium pyriforme in the } \\
\text { anamorphic stage Stegonsporium } \\
\text { pyriforme }\end{array}$ & Acer pseudoplatanus & 3 & 1 \\
\hline 13 & Valsa abietis & Juniperus communis & 1 & I \\
\hline 14 & Endophragmiella ellisii & Acer pseudoplatanus & 4 & III \\
\hline 15 & Lasiosphaeria phyllophila & Populus nigra & 4 & IV \\
\hline 16 & $\begin{array}{l}\text { Lasiosphaeria punctata }+ \\
\text { the anamorphic stage } \\
\text { Endophragmiella biseptata }\end{array}$ & $\begin{array}{l}\text { Fagus sylvatica, } \\
\text { Abies alba }\end{array}$ & 4 & IV \\
\hline 17 & Brachysporiella setosa & Fagus sylvatica & 4 & IV \\
\hline 18 & $\begin{array}{l}\text { lodosphaeria sp. in the anamorphic } \\
\text { stage Ceratosporium gracile }\end{array}$ & Alnus incana & 5 & II \\
\hline 19 & Eutypa sparsa & Populus nigra & 3 & III \\
\hline 20 & Libertella aucupariae & Sorbus aucuparia & 1 & 1 \\
\hline 21 & Daldinia childiae & Fagus sylvatica & 3 & II \\
\hline 22 & Daldinia fissa & Corylus avellana & 1 & I \\
\hline 23 & Nemania effusa & Populus nigra & 4 & II \\
\hline
\end{tabular}

ISSN 1996-4536 (print) • ISSN 2311-0783 (on-line) • Біологічні Студії / Studia Biologica • 2016 • Том 10/№1 • С. 133-142 
The end of the Table

\section{Cryptadelphia polyseptata in the}

24 anamorphic stage Brachysporium polyseptatum

25

Cryptadelphia sp. in the anamorphic stage Brachysporium obovatum

26 Fluviostroma wrightii
Fagus sylvatica

Acer pseudoplatanus, Alnus incana

Fagus sylvatica
6

II

6,5

III

5
II

Most of the established xylotrophic fungi were found on branches and twigs (19 species), while on stems -7 . The largest number of fungi (17 species) was found at the earliest decay stages (I and II), whereas in advanced decayed wood, the number of found species was lower, 6 xylotrophic pyrenomycetes at the III decay stage, and 3 species at the IV. At the $V$ decay stage, there were no species of xylotrophic pyrenomycetes found. Most of the identified xylotrophic pyrenomycetes are corticolous destructors of dead wood, a much smaller part constitute the lignicolous saprotrophs.

\section{CONCLUSION}

In this study, 26 new species of xylotrophic pyrenomycetes for the territory of Skolivski Beskydy were identified. These species represent 20 genera, 14 families, 8 orders, 3 subclasses (Hypocreomycetidae, Sordariomycetidae and Xylariomycetidae), the Sordariomycetes class, the Pezizomycotina subphylum in the Ascomycota phylum. Sordariomycetidae is represented by the largest number of species (17). The samples were found on thirteen species of tree substrates. The highest number of species (13) of the perithecial fungi were found on Fagus sylvatica L. Most of the established xylotrophic fungi were found on branches and twigs. The largest part of fungi was found at the earliest decay stages of dead wood by the Renvall scale.

\section{ACKNOWLEDGEMENTS}

We are sincerely grateful to Olexandr Akulov (Kharkiv National University named after V.N. Karazin) for his valuable advice in identifying some of the fungi collected.

We thank S.M. Zdenyanchyn for helpful comments and suggestions to the article (The Center for Scientific Research and Foreign Language Teaching of the NAS of Ukraine, Lviv Department).

1. Andrianova T.V., Dudka I.O., Hayova V.P. et al. (2006). Fungi of Ukraine, version 1.00. Website: http://www.cybertruffle.org.uk/ukrafung/eng/

2. Baxter A.P., E. van der Linde. Collecting and Preserving Fungi. A manual for Mycology. Pretoria, 1999. 96 p.

3. Boddy L., Watkinson S.C. Wood decomposition, higher fungi, and their role in nutrient redistribution. Canadian Journal of Botany, 1995; 73: 1377-1383.

4. Breitenbach J., Kranzlin F. (Eds.) Fungi of Switzerland. Vol. 1. Ascomycetes. Luzern: Mycologia, 1984. 310 p.

5. Bublyk Ya. Yu. Taxonomical structure and ecological features of xylotrophic pyrenomycetes in forests ecosystems of National Nature Park "Skolivski Beskydy". Scientific Principles of Biodiversity Conservation, 2015; 6(1): 61-78. (In Ukrainian).

6. Chronicle of Nature National Park "Skolivski Beskydy". Skole, 2012. 286 p. (In Ukrainian).

ISSN 1996-4536 (print) • ISSN 2311-0783 (on-line) • Біологічні Студії / Studia Biologica • 2016 • Том 10/№1 • C. 133-142 
7. Dennis R.W.G. British Ascomycetes. Vaduz: J. Kramer, 1981. 45 p.

8. Declerq $B$. The Sordariomycetes (Ascomycota) in Western Europe. Key to the species. Axelsvaardeken, 2011. 230 p.

9. Dudka I.O., Heluta V.P., Andrianova T.V. et al. Fungi of the Reserves and Natural Nature Parks, 2009. 427. (In Ukrainian).

10. Ellis M.B., Ellis P. Microfungi on land plants. An identification handbook. Berkshire: The Richmond Publ. Co., Ltd, 1997. 869 p.

11. Index of Fungi // CABI Bioscience databases. 2016. [Electronic resource]. Mode of access: http:// www.indexfungorum.org.

12. Kirk P.M., Cannon P.F., Minter D.W., Stalpers J.A. Dictionary of the fungi. $\mathbf{1 0}^{\text {th }}$ ed. CABI Europe. UK, 2008. 770 p.

13. Krupa J. Zapiski mykologiczne z okolic Lwowa i Podtatrza. Spraw. kom. fizyjogr, 1888; 22: 12-47.

14. Krupa J. Zapiski mykologiczne przeważnie z okolic Lwowa i z Karpat Stryjskich. Spraw. kom. fizyogr, 1889; 23: 141-169.

15. Küffer N., Gillet F., Senn-Irlet B. et al. Ecological determinants of fungal diversity on dead wood in European forests. Fungal Diversity, 2008; 30: 83-95.

16. Marynych A.M. (Ed.) The Nature of Ukranian SSR. Landscapes and physical-geographical regionalization. Kyiv: Nauk. Dumka, 1985. 224. (In Russian).

17. Medardi G. Atlante fotografico degli Ascomiceti d'Italia. Associazione Micologica Bresadola, 2006. 454 p.

18. Morochkovskiy S.F., Zerova M. Ya., Lavitska Z. G., Smitska M.F. (Eds.) Key to determining of fungi of Ukraine. T.2. Ascomycetes. Kyiv: Nauk. Dumka, 1969. 515 p. (In Ukrainian).

19. Mosyakin S.L., Fedoronchuk M.M. Vascular plants of Ukraine. A nomenclatural checklist. Kyiv: M.G. Kholodny Institute of Botany, 1999. 345 p. (In Ukrainian).

20. Munk A. Danish Pyrenomycetes. Copenhagen, 1957. 497 p.

21. Nordic Macromycetes. Vol. 1. Ascomycetes / Ed. L. Hansen, H. Knudsen. Denmark, 2000. $308 \mathrm{p.}$

22. Popov V.P., Marynych A.M., Lanko A.I. (Eds.). Physiographic zoning of the Ukrainian SSR. Kiev: Kiev University Press, 1968. 683 p. (in Russian).

23. Rappaz F. Taxonomie et nomenclature des Diatrypales a asques octospores. Mycilogia Helvetica, 1987; 2(3): 285-648.

24. Renvall $P$. Community structure and dynamics of wood-rooting Basidiomycetes on decomposing conifer trunks in Northern Finland. Karstenia, 1995; 3: 1-51.

25. Rogers K. (Ed.) Fungi, Algae, and Protists. Britannica Educational Publishing, 2011. 209 p.

26. Samuels G.J. Identification Workshop on the Hypocreales. Beltsville, 2007. 110 p.

27. Smitskaja M.F., Smyk L.V., Merezhko T.A. (Eds.). Key to determining of Pyrenomycetes of USSR. Kyiv: Nauk. Dumka, 1986. 364 p. (In Russian).

28. Schmidt O. Wood and Tree Fungi: Biology, Damage, Protection and Use. Berlin, Heidelberg: Springer, 2006. $334 \mathrm{p}$.

29. Webster J., Weber R. Introduction to Fungi. Third Edition. Cambridge University Press, 2007. 841 p.

ISSN 1996-4536 (print) • ISSN 2311-0783 (on-line) • Біологічні Студії / Studia Biologica • 2016 • Том 10/№1 • С. 133-142 


\section{ЕКОЛОГІЧНІ ОСОБЛИВОСТІ НОВИХ ДЛЯ СКОЛІВСЬКИХ БЕСКИДІВ ВИДІВ КСИЛОТРОФНИХ ПІРЕНОМІЦЕТІВ (АSСОМYСОТА)}

Я. Ю. Бублик

Львівський національний університет імені Івана Франка вул. Грушевського, 4, Львів 79005, Україна

Державний природознавчий музей НАН України, вул. Театральна, 18, Львів 79008, Україна e-mai: bublykyaroslav1302fungi@gmail.com

Польові збори були проведені з кінця вересня до початку грудня 2015 р., в основний період формування плодових тіл грибів. У цей час на території Сколівських Бескидів нами виявлені 26 нових видів ксилотрофнних піреноміцетів, що представляють 20 родів, 14 родин, 8 порядків, 3 підкласи (Hypocreomycetidae, Sordariomycetidae і Xylariomycetidae), клас Sordariomycetes, підвідділ Реzizomycotina у відділі Ascomycota. Підклас Sordariomycetidae представлений найчисленнішою кількістю видів (17). Шість видів ксилотрофних піреноміцетів належать до підкласу Xylariomycetidae. Найменшою кількістю видів (3) ксилотрофних піреноміцетів у лісових екосистемах Сколівських Бескидів представлений підклас Hypocreomycetidae. Лише три види належать до Incertae sedis Sordariomycetes. Усі нові ксилотрофні піреноміцети були знайдені на субстраті 13 видів з 11 родів деревних рослин. Найбільшу кількість видів (13) перитеціальних грибів зареєстровано на деревині Fagus sylvatica L. Більшість визначених ксилотрофних грибів (19 видів) були знайдені на відмерлих гілках і гілочках, тоді як на стовбурах дерев лише 7. Найбільшу кількість грибів (17 видів) знайдено на мертвій деревині ранніх стадій деструкції. Із виявлених представників ксилотрофних піреноміцетів більшість $є$ кортикофільними деструкторами відмерлої деревини, набагато меншу частину становлять лігнофільні сапротрофи. До кожного визначеного виду наведено його деревний субстрат, розміщення в екологічній ніші, а також спеціалізацію виду до стадії деструкції мертвої деревини за шкалою Ренвалла.

Ключові слова: ксилотрофні піреноміцети, екологічні ніші, лісові екосистеми, мертва деревина, Східні Карпати.

\section{ЭКОЛОГИЧЕСКИЕ ОСОБЕННОСТИ НОВЫХ ДЛЯ СКОЛЕВСКИХ БЕСКИД ВИДОВ КСИЛОТРОФНЫХ ПИРЕНОМИЦЕТОВ (АSСОМҮСОТА)}

\section{Я. Ю. Бублык}

Львовский национальный университет имени Ивана Франко ул. Грушевского, 4, Львов 79005, Украина

Государственный природоведческий музей НАН Украины ул. Театральная, 18, Львов 79008, Украина e-mail: bublykyaroslav1302fungi@gmail.com

Полевые сборы были проведены с конца сентября до начала декабря 2015 г., в основной период фрормирования плодовых тел грибов. В настоящее время на территории Сколевских Бескид нами обнаружены 26 новых видов ксилотрофных пиреномицетов, представляющие 20 родов, 14 семейств, 8 порядков, 3 подкласса

ISSN 1996-4536 (print) • ISSN 2311-0783 (on-line) • Біологічні Студії / Studia Biologica • 2016 • Том 10/№1 • С. 133-142 
(Hypocreomycetidae, Sordariomycetidae и Xylariomycetidae), класс Sordariomycetes, подотдел Pezizomycotina в отделе Ascomycota. Подкласс Sordariomycetidae представлен наибольшим количеством видов (17). Шесть видов ксилотрофрных пиреномицетов относятся к подклассу Xylariomycetidae. Наименьшим количеством видов (3) ксилотрофных пиреномицетов в лесных экосистемах Сколевских Бескид представлен подкласс Нуросreomycetidae. Только три вида принадлежат к Incertae sedis Sordariomycetes. Все новые ксилотрофные пиреномицеты были найдены на субстрате 13 видов из 11 родов древесных растений. Наибольшее количество видов (13) перитециальных грибов зарегистрировано на древесине Fagus sylvatica L. Большинство идентифицированных ксилотрофрных грибов (19 видов) были найдены на отмерших ветвях и веточках, тогда как на стволах деревьев только 7. Наибольшее количество грибов (17 видов) найдено на мертвой древесине ранних стадий деструкции. Из выявленных представителей ксилотрофных пиреномицетов большинство является кортикофильными деструкторами отмершей древесины, гораздо меньшую часть составляют лигнофиильные сапротрофы. Для каждого верифицированного вида приводится его древесный субстрат, размещение в экологической нише, а также специализация вида к стадии деструкции мертвой древесины по шкале Ренвалла.

Ключевые слова: ксилотрофные пиреномицеты, экологические ниши, лесные экосистемы, мертвая древесина, Восточные Карпаты.

Одержано: 02.02.2016

ISSN 1996-4536 (print) • ISSN 2311-0783 (on-line) • Біологічні Студії / Studia Biologica • 2016 • Том 10/№1 • С. 133-142 